\title{
RE: Evaluating additive versus interactive effects of copper and cadmium on life history
}

\author{
Tomoyuki Kawada ${ }^{1}$ (1)
}

Received: 12 May 2021 / Accepted: 2 September 2021 / Published online: 10 September 2021

(C) The Author(s), under exclusive licence to Springer-Verlag GmbH Germany, part of Springer Nature 2021

Keywords Copper $\cdot$ Cadmium $\cdot$ Daphnia pulex $\cdot$ Bioaccumulation

Sadeq and Beckerman (2020) conducted a risk assessment on the combined toxicity of copper $(\mathrm{Cu})$ and cadmium $(\mathrm{Cd})$ on Daphnia pulex. Both metals reduced ingestion rates, reduced reproduction, delayed maturation, reduced body size at maturity, and lowered somatic growth rate. Caution should be paid that there is an interaction between the metals, and the metal effects varied by D. pulex food levels and genotypes. As non-additive effect was observed by interactions, it is difficult to predict outcomes accurately. The authors used Daphnia pulex as an indicator of toxic effect. As there is another way to detect biological effect of the combined toxicity of $\mathrm{Cu}$ and $\mathrm{Cd}$ on plant, I present the information with special reference to non-additive effect of two metals on carrot.

An et al. (2020) examined the effects of mixtures of $\mathrm{Cu}$ and $\mathrm{Cd}$ on physiological measures and expression of growthrelated genes in carrot under greenhouse cultivation. According to the mixtures of $\mathrm{Cd}$ and $\mathrm{Cu}$ at higher concentration, the malondialdehyde content increased significantly and the proline content did not change. Under the combined pollution of $\mathrm{Cd}$ and $\mathrm{Cu}$, the level of damage in carrot via genetic and phenotypic changes increased non-linearly as $\mathrm{Cd}$ and $\mathrm{Cu}$ concentrations increased.

I previously reported the content of $\mathrm{Cd}$ and $\mathrm{Cu}$ in carrots (Lee et al. 1999; Kawada et al. 2002), and the content of copper in the soil did not correlate with the content of copper in the carrots. Regarding soil-plant discrepancy in copper, I speculated the reason as the low solubility of copper in the soil and the low intake into plant roots from the soil. Combination

Responsible Editor: Philippe Garrigues

Tomoyuki Kawada

kawada@nms.ac.jp

1 Department of Hygiene and Public Health, Nippon Medical School, Tokyo, Japan of $\mathrm{Cd}$ and $\mathrm{Cu}$ absorption in carrot from soil and combined toxic effect on carrot were not considered in our research. An et al. (2020) presented information that $\mathrm{Cd}$ and $\mathrm{Cu}$ absorption into carrots was closely related to genetic and phenotypic changes in carrot. Although human health effect was observed after the accumulation of toxic metals into critical organs, the process of two metal accumulations into plants and foods was complex. When conducting risk assessment of combined metals on human health, metal flows from inorganic to organic substances should be paid attention to understand the profound knowledge of ecosystem.

\section{Declarations}

Ethical approval This article does not contain any studies with human participants or animals performed by the author.

Informed consent There is no need of informed consent in this study.

Conflict of interest The author declares no competing interests.

\section{References}

An Q, He X, Zheng N, Hou S, Sun S, Wang S, Li P, Li X, Song X (2020) Physiological and genetic effects of cadmium and copper mixtures on carrot under greenhouse cultivation. Ecotoxicol Environ Saf 206: 111363

Kawada T, Lee Y, Suzuki S, Rivai IF (2002) Copper in carrots by soil type and area in Japan: a baseline study. J Trace Elem Med Biol 16: $179-182$

Lee YZ, Suzuki S, Kawada T, Wang J, Koyama H, Rivai IF, Herawati N (1999) Content of cadmium in carrots compared with rice in Japan. Bull Environ Contam Toxicol 63:711-719

Sadeq SA, Beckerman AP (2020) Evaluating additive versus interactive effects of copper and cadmium on life history. Environ Sci Pollut Res Int 27:2015-2026

Publisher's note Springer Nature remains neutral with regard to jurisdictional claims in published maps and institutional affiliations. 